\title{
A Contrastive Study of Modulation in English and Arabic
}

\author{
Mohammed Jasim Betti ${ }^{1} \&$ Zainab Kadim Igaab ${ }^{2}$ \\ ${ }^{1}$ Dept. of English, College of Education for Humanities, Univ. of Thiqar, Iraq \\ ${ }^{2}$ Dept. of English, College of Education for Humanities, Univ. of Thiqar, Iraq \\ Correspondence: Mohammed Jasim Betti, Dept. of English, College of Education for Humanities, Univ. of Thiqar, Iraq.
}

Received: February 8, 2018 Accepted: March 1, 2018 Online Published: March 21, 2018

doi:10.11114/ijecs.v1i1.3120 URL: https://doi.org/10.11114/ijecs.v1i1.3120

\begin{abstract}
Modulation is a term that denotes using modals and other constructions to refer to such functions as ability, obligation, permission and willingness. The present study is descriptive and contrastive. The aim of this study is to describe English and Arabic in terms of modulation as manifested in the four mentioned functions. The study starts with giving a description of modulation in English and Arabic. The following step is making comparisons regarding the four functions successively. The study concludes that this phenomenon is found in both languages with the existence of a number of differences in addition to some similarities.
\end{abstract}

Keywords: Contrastive Linguistics, Grammar, Modulation, English, Arabic

\section{Introduction}

The constraining factors of modal verbs can be divided into two groups. The first group includes permission, obligation and volition which involve some kind of intrinsic human control over events (denotic), and the second consists of possibility, necessity and prediction which do not primarily involve human control of events, but do typically involve human judgment of what is or is not likely to happen (extrinsic).

This study deals with the factors stated in the first group, that is modulation which means the use of modal auxiliaries to express willingness, ability, permission, obligation (Al-Hamash and Abdullah, 1976: 144). The term is different from other terms like 'mood, modality'.

The topic has not been investigated within the field of contrastive analysis. Modal verbs can also be considered as a source of confusion since each modal auxiliary has more than one meaning.

In this study, the term modulation does not deal with alternations of stress and intonation which forms a part of the phonological process and refers to the differences in paralanguage (see Hall, 1969: 179 and Matthews, 2007: 249).

The aim of the paper is to give a description of the modals expressing ability, obligation, permission, and willingness in the two languages. Then the results of the study accept its hypothesis which is that modulation exists in English and Arabic with a number of similarities and differences.

The examples in the English section are written in English and those in the Arabic section are transliterated using the Iraqi Arabic phonemic symbols and then they are translated into English. The same is with all the syntactic and semantic terms used in this paper.

\section{Literature Review}

\subsection{Ability in English and Arabic}

In the following section, the structure and function of ability in English and Arabic are compared.

\subsubsection{Ability in English}

Can and could express physical mental ability (power and capacity) and possibility (Quirk et al., 1985: 221 and Eastwood, 2003: 108-10):

(1) Can you remember where I live?

(2) Magda could speak three languages at the age of six.

Can is used to describe ability and cannot describes a lack of ability in the present: 
(3) She can't speak Italian.

The notion of ability is also expressed by be able to and be capable of. That notion is closely related to theoretical possibility:

(4) Will you be able to meet us in London tomorrow? (Leech and Svartvik, 1994: 146).

When ability in the present is surprising or involves overcoming some difficulty, is/are able to will also be used:

(5) Despite his handicap, he is able to drive a car.

Be able to is used in the active not the passive voice (Foley and Hall, 2005: 174). It is always a special finite. Can is synonymous with be able to. Can is used with the present and future time and requests:

(6) I can answer your question right now. (present)

(7) I can meet you in two hours' time. (future)

(8) Can I have a cup of tea? (Eastwood, 2002: 124-5).

Can is also used in polite offers of help:

(9) Can I help you with carrying these books?

On the other hand, Cannot expresses 'Not to be allowed to do something'.

(10) You cannot park here.

Could expresses ability for past and future. It sometimes refers to the ability which no longer exists:

(11) When I was younger, I could jump higher. (past)

(12) I think I could see you tomorrow at eight o'clock. (future)

Could have + past participle expresses a past opportunity to do something which was not done:

(13) I could have gone to England last Summer.

Couldn't have + past participle does not express the negation of the action but it means one situation was made impossible because of another situation:

(14) John couldn't have broken the window. He was not here all day.

But in the negative sentence, could is also used:

(15) I could not swim ten miles.

Could is not always equivalent to was/ were able to. If the reference is to something that can be done because of knowledge or skill, could or was/were able to may either be used (Al-Hamash and Abdullah, 1976: 240-2 and Eckersley and Eckersley,1981: 197-8).

(16) I could (was able to) swim when I was six years old.

The future tense is indicated by will be able to:

(17) When he is older, he'll be able to be left a hundred weight. (Palmer, 1966: 116)

The adjective able is used to convey the meaning "good at what you do":

(18) He is an able student.

To use present perfect, be able is preferred:

(19) Since his accident he hasn't been able to leave the house.

Be able to is also used in the past perfect:

(20) He said he had lost his passport and hadn't been able to leave the country.

Could is used as a more polite form of can when asking someone to do something:

(21) Could you give me your game?

Capable (of) is used to express the following:

'able to do things well':

(22) She's a very capable young woman.

'able to do something':

(23) I know she is capable of good work. 
Could is used to indicate the present meaning when the conditional meaning is expressed:

(24) Could you run the business by yourself? (if this was necessary). (Thomson and Martinet, 2001: 135).

\subsubsection{Ability in Arabic}

Ability can be translated into Arabic as (alqudrah, almaqdirah, alistiTa9ah). It is shown by the following: the verbs (yastaTii9, yaqdir, yumakin) for (can, could):

(25) Can you drive? hal tastaTii9 alsiyqa?

(26) Can I help you? hal yumkinuny musa9adatuka?

(27) I could not see him. La yumkinuny ru? yatuhu.

(28) Could you lend me two dinars? hal bi?imkanika ?i9araty dinarayn?

(29) He could speak two languages when he was nine. kana qadiran 9ala altaHaduӨi biluǵatayni Hina kana fy altasi9a

(30) We could have got to the station earlier, but we didn't try. kuna nastaTii9a alwuSool ila almaHaTah mubakiran, walakinana lam nuHawil Dalika.

(31) He could not have damaged your bike. He was with me all evening. lam yakun bi?imkanihi itlaf darrajatuka li?anahu kana ma9y Tawala allayali.

Ability can also be expressed by the adjectives (qadir, qadiir, mu?ahal) for (be able to); the phrases (qadir 9ala, qabil li) for (be capable of); and the nouns (qudrah, maqdirah).

There is a difference between (alqudrah) and (al?istiTa9ah) which means the response for something or someone. For example,

(32) hal yastaTii9a rabuka?, which means that

Can Allah respond to what I ask Him to?

This example shows that alistiTa9a means alijaba, while

(33) la yastaTii9oona suHqan, means that it is difficult for them to listen to the Holy Quran. It does not mean that they are unable to do. So, alistiTa9ah does not mean alqudrah (Khalil, 1999: 218 and Al-Askary, 2003: 126).

Alqudrah is more general than alistita9ah. The first is not restricted by any circumstance while the second is. For example, a person is able to carry a heavy stone but he can not do it because of his sickness. Aalqudrah concerns Allah and His actions while alistiTa9ah belongs to the human being:

(34) (wa lillahi 9ala alnasi Haja albayti man istaTa9a ilayhi sabila).

Furthermore, Alqadir and almutamakin), (al?iqdar and altamkiin) are different. For example, a person can write something by using a typewriter. So, altamakun results by the aid of the machine and the place where a person can do something. But, alqadir is taken from alqudrah. So, a person can give up the machine with which he can write something but he cannot give up alqudrah, as in:

(35) (Makanahum fy al?arși ma lam numakinna lahum). (Al-Askary, 2003: 127 and Al- Duury, 2005: 183-4).

According to Aziz (1989: 85), such a notion also sheds light on lexical verbs like:

(36) (I can see a man coming towards us).

Ara rajulan qadiman naHwana.

(37) (Ali can speak French fluently).

9ali yatakalamu ?alfaransiyah biTalaqah.

The negative ability is expressed by the particle (la):

(38) (Layla can not hear anything).

Layla la tastaTii9u an tasma9a šay?an. 


\subsection{Obligation in English and Arabic}

\subsubsection{Obligation in English}

Obligation is one of the directive speech acts with which the speaker intends to oblige someone not to do some actions. It can be achieved by one of the following ways:

a) a declarative sentence: is a type of sentences used by a speaker to impose his/her authority on the hearer (s). Such a way includes a number of constructions: i) $\mathrm{Be}+$ to + infinitive: Some grammarians confirm that this construction expresses obligation by ordering the speaker to do something by his official authority:

(39) You are to write your name on each page.

ii) $\mathrm{Be}+$ supposed to: This way is used by the speaker to order people to do things under rules:

(40) You are supposed to start working at 8.30 every morning.

iii) Need (to) + infinitive: Need is used with different forms in the past and present when it expresses obligation:

(41) I need a new suit.

(42) He needs to go there.

(43) He needed to escape.

iv) Infinitive clauses:

(44) I do not know what to say.

v) Indirect questions: Their structure a wh-word followed by a to infinitive:

(45) I wonder who to invite.

b) An interrogative sentence: With those sentences, the hearer (s) does not expect the answer to be something else except the order of doing a certain action:

(46) How many times do I have to tell you not to lick your plate.

c) The nouns 'obligation, necessity, and compulsion' occur to denote obligation:

(47) If, through carelessness, someone damages your bicycle, he is under a legal obligation to pay the cost of repairs.

(48) There is no necessity for you to do that.

(49) A defeated enemy usually signs a treaty under compulsion.

d) A number of adjectives like 'compulsory, obligatory, and necessary' are used to express obligation:

(50) Military service is compulsory in many countries.

(51) Is attendance at school obligatory?

(52) It is not necessary for you to do that.

e) The following verbs: oblige, compel, require, be liable to are also used to indicate obligation:

(53) In most countries the law obliges/ requires/ compels parents to send their children to school.

f) The modal auxiliaries must, have (got) to, ought to/ should, shall, and will are also used to refer to obligation:

One of the two meanings of must is obligation or compulsion:

(54) You must be back by 10 o'clock.

Must does not refer to past obligation only in reported speech since it is used to affect the people's behaviour and such a thing is not found in the past. So, had to is used instead of must:

(55) I had to cycle three miles to school when I was a child.

Must has a number of negative forms which are need not, do not have to, not obliged to, must not (be obliged not to, not be allowed to:

(56) You need not/ do not have to/ are not obliged to be back at 10 o'clock.

(57) You must not ill-treat children (Quirk, et al., 1985: 62 and Swan, 1995: 335).

Have (got) to is used to express obligation:

(57 a) You have to (You've got to) work hard nowadays to make a living (Eckersley and Eckersley, 1981: 196).

Should expresses present and future obligation: 
(58) I should see a dentist soon.

Should + be + verb (ing) expresses present- moment obligation to perform an action which is not achieved.

(59) We should be studying our lesson for the final examination.

Should have + past participle expresses past obligation that was not performed:

(60) I should have seen a dentist (Al-Hamash and Abdullah, 1976: 243.

Ought to expresses obligation (and desirability). It is synonymous with should:

(61) We ought to be more careful with our money.

Ought to be + verb (ing) expresses present -moment obligation and also past obligation that was not fulfilled:

(62) John ought to be solving the problems.

(63) We ought to have visited our neighbours (Al-Hamash and Abdullah, 1976: 243). .

Ought to bel do something is used to say what you expect to be true or you expect something to happen:

(64) She ought to be here by now.

Will and shall are used to express obligation (and volition and futurity) (ibid: 162).

(65) We shall come about 3:00 p.m.

Shall expresses self-imposed obligation with the first person pronouns and the promise or threat will be the result (Chalker, 1984: 121).

Will involves an obligational sense.

Obligation occurs with three degrees of strength: weak, medium, and strong: should, ought to, may not, cannot denote weak obligation; be supposed to and had better convey medium obligation; and must, must not and have to express strong obligation.

Past obligation is expressed by had to, could, and was/were allowed.

The negation of obligation is prohibition. Permission and obligation belong to the same speech act, which are directives, and they are related to the same type of modality denotic (extrinsic).

\subsubsection{Obligation in Arabic}

Obligation is (ilzam, wajib, ijbar) (yujbir, yulzim). There is a difference between alluzoom and alilzam . Alluzoom is only used with alHaq (the right):

(66) lazima alHaqu (the right is obliged) but not

(67) lazima albaTil (the falseness is obliged) while alilzam is used with both alHaq and albaTil: (alzamahu alHaq wa alzamahu albaTil) (Al- Askary, 2003: 253).

Obligation can be expressed by the following:

a) the verbs (yajib, yanbagy); the preposition (9ala) followed by an appropriate personal pronoun in addition to other constructions like (yajib 9alayhi an, yataHatam 9alayhi an, wajaba 9alayhi an, ta9ayana 9alayhi an, tarataba 9alayhi, yanbaǵy 9alayhi aw lahu an, yajib an, 9alayka an, labuda li):

(68) You must stay here.

(yajib/ yanbaǵy an tabqa huna).

(69) He must pay the bill.

(9alayhi ?an yadfa9a alHisaba).

(70) You must say the truth.

(9alayka an taqoola lHaqa).

(71) She should do her best.

(9alayha an taf9ala ma biwis9iha).

(72) You ought to be here by now.

(labuda an taf9ala $\dot{\check{s} a y ? a n) .}$

(73) You have to be present. 
(9alayka ?an taHṣar).

(74) You are under no obligation with regard to that matter.

(la 9alayka min Dalika.)

b) To express the negative form, the following are used: (yanbaǵy an la, ma yanbaǵy, la yalzam an, la da9y li? an, laysa 9alayka an):

(75) You must not do this.

(Ma yanbaǵy an taf9ala haDa, yanbaǵy an la taf9ala haDa, 9alayka an la taf9ala haDa).

Prohibition is expressed by Must in the negative form:

(76) You needn't/ don't have to pay now.

(La yalzam an tadfa9a alaan.)

(77) You needn't have done that.

(Ma kana an taf9ala haDa, lam takun mulzaman bi9amali haDa.)

(Aziz, 1989: 86, 88 and Khalil, 1999: 221, 226).

Have to is used like must. Although must and have to express obligation, they are different from each other. With must, obligation is imposed by the speaker/ writer, while have to results by the external forces or circumstances. The feature which distinguishes must from other modals is that the speaker associates himself/herself with obligation:

(78) I had to leave the class early.

(Kana 9alayah an uǵadir alSaf mubakiran.) (Khalil, 1999: 222).

c) the imperative verb for males or females:

(79) "fa?if9alu ma tu?maroon" (/albaqarah:68). (They said, "Beseech on our behalf your Lord to make plain to us what (heifer) it is!"). (Alsamarra?i, 2005: 27 and 9abdulHamiid, 2010).

d) warning someone:

(80) Do not lie.

(iyakum wa alkaDib). (Al-Farraa?, 1955: 2 and Al- Samarra?i, 2003: 89).

e) lam al?amur (the command lam):

(81) (let me go to him) (the command for the speaker).

(li?aDhab ilayhi).

(82) (Let Khalid tell him about what happened) (the command for the listener).

(liyaxburahu xalid bima Hada $\Theta a$ ). (Al-Samarra?i, 2003: 6).

f) illa which is the result of the combination between the two particles: an + la :

(83) (Ataytuka illa tukalima alnasa lisab9i layalin sawiyan). (Al-Farraa?, 1955: 213).

g) (la alnahiyah) is one of the Arabic devices by which the listener but not the speaker is meant to be stopped doing something:

(83) (la uriyanaka hahuna) which means that "do not be here in order not to see you". (Al-Samarra?i, 2005: 6).

h) the condition:

(84) (fa?in qataluukum fa?iqtiluuhum) ('Al-Baqarah: 191') (And slay them wherever you catch them, and turn them out from where they have turned you out).

AlSamarra?i, 2005: 47).

Although the meaning expressed by must is obligation but there are some expressions which are also indicated by:

(85) Orders must be filled. (Talabatu wajibata altanfiiDa).

(86) It must not go any further. (Ubqi haDa al?amur bayny wa baynaka).

(87) There must be some mistake. (hunaka xaTa? Fy al?amur.)

(88) What goes up must come down. (Ma Tara Tayrun wa irtafa9 illa kama Tara waqa9.)

\subsection{Permission in English and Arabic}




\subsubsection{Permission in English}

Permission is an act of allowing or permitting someone to do something, especially when such an act is done and somebody has an authority but the speaker does not have that authority. The speaker agrees with someone to do something by giving or asking him for agreement.

Permission is expressed by the following ways:

a) lexical verbs (allow, permit, let, mind):

(89) Will you permit (allow) me to use your bicycle?

(90) My doctor won't let me get up yet.

(91) Would you mind if I opened a window? No, I don't mind at all.

Allow and permit are used to refer to permission in the past and future time:

(92) During the curfew, nobody was allowed to be out after sunset. (past)

(93) Shall we be allowed (permitted) to stay up late on new year's Eve? (future) (Hornby, 1968: 220 and Leech and Svartvik, 1994: 163).

The past permission is indicated by the following constructions: the noun 'permission' and the two verbs 'allowed, permitted':

(94) Miss Liu had permission / was allowed (permitted) to leave class early.

Negating the sentence in which allowed to/ permitted are used expresses the meaning of prohibition. For example,

(95) You are not allowed to borrow my car (Quirk., et al, 1985: 222).

Permission is also referred to by using an imperative sentence:

(96) Come in.

In the example No. (96), it is not an order given by the speaker to the hearer but he allows him to enter the house or the room after his knocking at the door, that is, it is a request of his permission (Lyons, 1977: 837).

Permission can be indicated by one of the nominal and adjectival expressions like the noun permission and the adjectives permissible and allowed:

(97) The manager gave his typist permission to leave early.

(98) It is permissible/ allowed for me to build here. (Jackson, 1992: 104).

But there are some expressions used to refuse permission include cannot, may not, must not, and not allowed/ permitted (to):

(99) I'm afraid you can't just walk in here.

(100) Customs may not bring their own food into this café.

(101) Tourists must not take money out of the country.

(102) The use of mobile phones is not allowed/ permitted in the library.

Furthermore, permission is referred to by one of the modal auxiliaries which are can, could, may, and might. One of those modals which is can has a number of uses. One of those uses is giving permission:

(103) Anyone can join the club; asking for permission:

(104) Can I take your umbrella? ; and talking about permission:

(105) I can stay up late as I like. My parents don't mind (Quirk, et al., 1985: 223 ; Eastwood, 1994: 119-120 and Betti et al. 2018: 2).

But the use of could is more tentative than can in asking for permission:

(106) Could you help me with this math problem?

General permission in the past is expressed by could while the past permission in a specific occasion is indicated by was/ were allowed to:

(107) I was allowed to leave early yesterday.

In colloquial speech, can is used to replace the more formal may to express permission (Eckersley and Eckersley, 1981: 197; and Quirk and Greenbaum, 1991: 60). May is used in formal situations while can is in less formal ones. Giving and 
asking for permission but not talking about are performed by may:

(108) Any person over 18 years may apply to join the club.

(109) May we come in?

Might is used tentatively more than may and the former exists in the indirect question structures:

(110) Might I smoke in here?

(111) I wonder if I might have a little more cheese.

Pragmatically speaking, permission is one of the directives that tries to make the hearer do something. Explicit and implicit performative utterances are used to convey permission. Explicitly, the performative verbs like permit, allow, authorize, and consent are used while implicitly, it is expressed by using one of the modals: can, could, may, and might. Those modals have the implicit use of permission because more than one meaning can be expressed by one modal. For example, can conveys the following meanings: permission, ability, possibility, willingness, and sensation:

(112) You can come tomorrow.

(113) I can read Greek.

(114) He can be there now.

(115) Can you pass the salt?

(116) I see the moon.

Furthermore, an imperative sentence is used to refer to permission implicitly:

(117) Shut the door if you like.

\subsubsection{Permission in Arabic}

Permission (tarxiiS, ruxSah, iDn) is expressed by: (yastaTii9, yumakin, ya?Dan) (hal mina almumkin an) (fa (adat aldu9aa?) and (imperative verbs) for the modal verbs (may, might, can, could) and the lexical verb (allow):

(118) You can/ may borrow my book.

(tastaTii9a/ yumkinuka an tasta9iira kitaby).

(119) You could have borrowed my car.

(Kana yumkinuka isti9arata sayaraty/ bi? imkanika an tasta9iira sayaraty.)

(120) Could I leave now?

(A? astaTii9u almuǵadarah alan/ Aymkinuny an uǵadir alan?)

(121) May/ Might I borrow your pen?

(Aymkinuny an asta9iira (isti9arat) qalamuka?)

(122) I allow him to do something.

(A? Dan lahu bifi9il śay? an ma.)

(123) (You may come in).

(Idxul.)

(124) (You may borrow my pen).

(xuD qalamy.)

(125) (You can go now).

(IDhab alan.)

(126) (He may do what he likes).

(lahu an yaf9ala ma yas்aa?.)

(127) You may sit here.

(Laka an tajlusa huna.)

In addition, this notion is found by the imperative mood:

(128) The girl accepted the bridal money.

(rașiyat albint bilmahr.) 
The negative form of permission is shown by the particle (laysa):

(129) You may not/ should not say this.

(Laysa an taqoola haDa.) (Aziz, 1989: 85-6; Khalil, 1999: 218-20; Al-Askary, 2003: 256 and Ibn Al-Naṭim,1342: 306).

One of the meanings of permission in Arabic which is al?iDn has two meanings:

a) alsam9, al?inSat, alTa9a and alxișoo 9 which means that someone will obey every instruction when permission is given by heaven:

(130) 'IDa alsama? a inšaqat wa aDinat lirabiha wa Huqat' (Al- Inšiqaq: 1-2).

(When the Sky is rent asunder; And hearkens to (the Command of) its Lord, and it must need (do so)) .

b) altarxiiS and al?ibaHah if it is given by Allah:

(131) 'Qul ar?aytum ma anzala Allahu lakum min rizqin faja9altum minhu Haraman

wa Halalan qul Allahu aDina lakum am 9ala Allahi Taftaroon ' (Yoonis: 59).

(Say: "Do you see what things Allah has sent down to you for sustenance? Yet you hold forbidden some things thereof and (some things) lawful.

(Say: "Has Allah indeed permitted you, or do you invent (things) to attribute to Allah?")

In addition, there is a word derived from iDn which is ista?Dana. It means that a person asks for another person's permission:

(132) "Innama almu?minoona allaDiina amano billahi warasoolahu wa?iDa kanu ma9ahu 9ala amirin jami9in lam yaDhabu Hata yasta?Dinuhu. Inna allaDiina yasta?Dinuka ula?ika allaDina yu?minuuna billahi warasulihi fa?iDa ista? Danuka liba9Di s̆a?nihim fa? Din liman š̉?ta mihum wa istaǵfara Allahu inna Allahu ǵafurun raHiimun" (Alnuur: 62).

(Only those are believers who believe in Allah and His Messenger. When they are with him on a matter requiring collective action, they do not depart until they have asked for his leave; those who ask for your leave are those who believe in Allah and His Massenger; so when they ask for your leave, for some business of theirs, give leave to those of them whom you will, and ask Allah for their forgiveness, for Allah is Oft-Forgiving, Most Merciful).

In the above Quran ayah, the verb (yasta?Din) is used to ask the prophet for giving the believers permission to do something (Al- Owiny: 201-2).

\subsection{Willingness in English and Arabic}

\subsubsection{Willingness in English}

Few types of volition can be distinguished which are willingness, wish, intention and insistence. They are listed in the order of increasing strength (Leech and Svartvik, 1994: 161 and Downing and Locke, 2006: 385-6 ).

According to what the learners of the language think, will and shall are used to refer to futurity, but those two modals are used to denote a number of different meanings although shall is regarded as the modal of the least use in comparison with the others. Willingness can be expressed by the auxiliary will:

(133) Will you lend me those pens?

Here, the future meaning of will is mixed with that of volition. In the real life speech, can, could, will, would are used almost interchangeably in requests, although some of the modals do a better job than others in coming across as polite:

Some of the modality types the representative modal verbs

Physical/ mental ability can/ could

Granting permission can, could, may, will,

Obligation must, should

(Teschner and Evans, 2007: 83).

Will is used to express willingness (promise or determination) in the two examples No. 141, 142, the determination or promise is in the speaker's mind:

(134) All right, I will pay you at the rate you ask. (willingness)

(135) I won't forget my son's birthday. (promise) 
(136) I will make this radio work even if I have to stay up all night. (determination) (Eckersley and Eckersley, 1981: 165).

Both (a) Read the book!

(b) Read the book, won't you! are imperatives but

(137) You will read the book! is more forceful and common primarily in contexts such as military training (Falk, 1978: 194-5).

Will is used to talk about what someone or something is willing or able to do, such as offers, invitations, requests, and orders. But will not or won't is used to refer to unwillingness to do something:

(138) I'll give another opportunity to get the correct answer.

(139) Mum! Sue won't give me back my pencil case.

Will not has another use which is that a person wants to refuse a thing to work in the way it should:

(140) The key won't fit the lock.

Would is used to refer to general or repeated willingness in the past but if there is a specific occasion, would can not be used:

(141) Whenever I had to go to town, Ron would give me a lift. (repeated)

(142) I was late, so Ron gave me a lift to town; while would not is used for both unwillingness in general or in a particular occasion:

(143) We thought that people wouldn't buy the book.

(144) She wouldn't say what was wrong when I asked (Hewings, 1999: 36).

Other constructions can be mentioned. Be willing to do something (including willing as an adjective) is used to express: "to be happy to do something":

(145) He's willing to lend us his car.

Willing is used to express "wanting to do something":

(146) He's a very willing assistant.

2.4.2 Willingness in Arabic

Willingness (alraǵbah, aliradah) is expressed by the verbs: yawad, yarǵab, yuriid, yaš̉aa?; nouns: 9azim, taSmiim, raǵbah, ?iradah, maš̉i?a , and some expressions: 9an Tiib xaTir (willingly). For example,

(147) (I want the goodness only for him and I do not want the badness).

(uridu lahu alxayr.) (Al- Aaskary, 2003: 138).

(148) (He won't pay this sum.)

(La yuriidu an yadfa9 haDa almablaǵ.)

(149) "yawma?iD yawadu allaDina kafaru".

(150) (I'm willing to do something).

(raǵibun bifi9li š̀ay?un mu9ayanun.)

The negative form of willingness is expressed by (lan):

(151) (He won't come to the show tomorrow).

(Lan ya?ti ǵadan ila alma9raș.) (Aziz, 1989: 85 and Al- Maliky, 2000: 3).

It is important to differentiate among the following three terms (aliradah, almaši?ah, and al9azm). Aliradah concerns with future only. Similarly, the notion 'willingness' expresses futurity. Aliradah and almaš̀i?ah are different. The person has his iradah under all the circumstances. For example, I said this whether Zaid accepts it or not, i.e. his iradah is against Zaid's refusal. But almaši?ah means that a person wants something he may get or he may not. Similarly, al9azm and almaš̀i?a are different. Al9azm means that a person determines to do something (Al- Askary, 2003: 140, 142).

Willingness is also expressed by a number of particles like (layta, sawfa, alsiin):

(152) (We hope Saeed will travel with us).

(Layta sa9iidan yusafiru ma9ana.)

(153) I will help you. 
(sawfa usa9iduka.) (Khalil, 1999: 224 and Al- Samarra?i, 2005: 277).

There are other expressions used to refer to that notion:

(154) invocation: "Rabana iǵfir lana Dinuubina wa kafir 9ana say?atina wa tawafina ma9a al?abrar".

(155) "Liyaǵfir Allahu laka".

(156) the perfect: "YarHamuka Allahu". (God bless you). (Al- AnSary:69 and Al- Samarra?i, 2005: 7).

In addition, willingness deals with impossibility:

(157) (I wish youth will return).

(Layta als̆ababu ya9uudu.)

But the unexpected possibility is not concerned with by willingness. If it is expected, it will become within the domain of begging and it is not obligatory to happen. With willingness, the thing that we want to happen, may or may not happen:

(158) (Layta ǵadin atin.) because tomorrow should come so it is wrong to use willingness with such sentences (AlSamarra?i, 2005: 277).

It should be noted that although sawfa and alsiin are used to refer to willingness but they are different in their use. sawfa is of strong effect rather than alsiin. This will be explained in the following two examples.

What the prophet Yacob said to his sons was because of what they did to their brother Yousuf, i.e. a horrible and disastrous action:

(159) "Qala sawfa astaǵfiru lakum raby" (Yousuf: 98).

(He said, "Soon will I ask my Lord for forgiveness for you);

while the prophet Abraham said to his father when he asked him to be Muslim and there was no response:

(160) "sa?astaǵfiru laka raby innahu kana bi Hafiyan" (Maryam: 47).

"Peace be on you. I will pray to my Lord for your forgiveness, for He is to me Most Gracious) (Al- Samarra?i, 2005: 22).

\section{Results}

A number of the findings of the comparison between English and Arabic in terms of ability, obligation, permission and willingness are arrived at:

1. In English, ability in the past, present and future is expressed by the two modals can and could while in Arabic, it is expressed by a limited number of verbs, adjectives, fixed phrases, and nouns. In English, ability has one meaning but in Arabic it has more than one meaning. Those meanings are different from each other and they are used differently from one situation into another. The English negative ability is done by the auxiliary followed by the particle of negation not while the Arabic negative ability is done by one particle.

2. In English, obligation is expressed by a number of ways like declarative sentences, interrogative sentences, nouns, adjectives, verbs, and modal auxiliaries. In Arabic, it is expressed by a number of verbs, a preposition and other constructions, an imperative verb, warning someone, particles and the use of the condition. Negatively, in English, it is expressed by one of the modals accompanied by not while in Arabic, a verb is followed or preceded by particles.

3. Permission is expressed by a limited number of lexical verbs, an imperative sentence, nominal and adjectival expressions, and a number of modals. In Arabic, a limited number of verbs, fixed expressions, particles, imperative verbs and modals are used to refer to permission. In English, negation is indicated by one of the modals followed by not while in Arabic, it is expressed by a particle.

4. In English, willingness is expressed by the use of a modal (one or two only). Its negative form is constructed by using that modal followed by not. In Arabic, nouns, verbs, particles, and some expressions are used to refer to willingness and its negative form is constructed by a particle. 


\section{Conclusion}

1. In Arabic, alqudrah and alistiTa9ah are different but in English both refer to ability. Likewise, in Arabic, there is also a difference between (alqadir and almutamakin), (aliqdar and altamkiin) but they are the same in English. Likewise, in Arabic, ability is expressed by a number of devices: lexical verbs which are equivalent to the modal auxiliaries; be able to which includes the adjective able; be capable of which can be considered as an adjective followed by of phrase; and nouns to nouns. Its negative counterpart is expressed by either (la) or (laysa), while in English it is done by attaching the particle $n o$ ' to one of the modal auxiliaries. In addition, in English, both can and be able to are synonyms but in Arabic, yastaTii 9 and yaqdur, for example, are not.

2. In English, obligation is referred to by sentences (declarative, interrogative), nouns, verbs, adjectives, and modals while in Arabic, it is expressed by lexical verbs, prepositions followed by a pronoun, particles, warning or condition, in addition to other constructions like verb + preposition.

3. In English, the devices which are used to express permission are lexical verbs, nouns, adjectives, modals, and imperative sentences while in Arabic, it is indicted by lexical verbs, invocation particles, particles, alhamza + verb, preposition + pronoun, an imperative sentence.

4. In English, there are two devices to express willingness which are modal verbs and be willing to but in Arabic, there is a number of the devices: lexical verbs, nouns, particles, invocation, and other expressions.

To express unwillingness in English is by attaching not to will, would while in Arabic, (lan) is used for negation.

5. The results of the study support its hypothesis which is that modulation is available in the two compared languages, and there are differences and similarities between the two languages in terms of ability, obligation, permission and willingness.

\section{Acknowledgments}

We acknowledge our indebtedness to the librarians at the college of education for humanities and the central library in our university.

\section{References}

\section{English References}

Al-Hamash, K. I., \& Jamal Jalal Abdullah (1976). A Course in Modern English Grammar. Baghdad: IDELTI.

Ali, Abdullah Yusuf (trans.) (2012). The Quran: The Meaning of the Glorious Quran. Asir Media.

Betti, M. J., Zainab, K. I., \& Muna T. (2018). "The Iraqi EFL Learners' Use of Permission, Obligation and Prohibition". International Journal of English Linguistics, 8, 3, 251-69.

Biber, D., S. Johansson, G. L., Susan, C., \& Edward, F. (2000). Longman Grammar of Spoken and Written English. London: Longman.

Celce-Murcia, M., \& Larsen- Freeman, D. (1999). The Grammar Book: An ESL/ EFL Teacher's Course. $2^{\text {nd }}$ edn. Boston: Heinle and Heinle.

Chalker, S. (1984). Current English Grammar. London: Macmillan.

Downing, A., \& Philip L. (2006). English Grammar. A University Course. $2^{\text {nd }}$ ed. London: Routledge.

Eastwood, J. (1994). Oxford Guide to English Grammar. New York: Oxford University Press.

Eastwood, J. (2002). English Grammar. Oxford: Oxford University Press.

Eastwood, J. (2003). Oxford Practice Grammar. Oxford: OUP.

Eckersley, C. E., \& Eckersley, J. M. (1981). A Comprehensive English Grammar. London: Longman.

Erwin, W. (2004). A Short Reference Grammar of Iraqi Arabic. Washington, D.C.: Georgetown University Press.

Falk, Julia, S. (1978). Linguistics and Language: A Survey of Basic Concepts and Implications. New York: John Wiley and Sons.

Foley, M., \& Diane, H. (2005). Longman Advanced Learners' Grammar: A self-study reference and practice book with answers. London: Longman.

Hall, R. (1969). Introductory Linguistics. Delhi: Chilton.

Hewings, M. (1999). Advanced Grammar in Use: A self study reference and practice book for advanced learners of English. Cambridge: CUP. 
Hornby, A. S. (1968). A Guide to Patterns and Usages in English. London: Longman.

Greenbaum, S., \& Randolph, Q. (1991). A Student's Grammar of the English Language. London: Longman.

Jackson, H. (1992). Grammar and Meaning: A Semantic Approach to English Grammar. London: Longman.

Krohn, R., \& the staff of the Michigan English Language Institute. (1971). English Sentence Structure. Ann Arbor: The University of Michigan Press.

Leech, G., \& Svartvik, J. (1994). A Communicative Grammar of English. $2^{\text {nd }}$ edn. London: Longman.

Lock, G. (2003). Functional English Grammar: An Introduction for Second Language Teachers. $6^{\text {th }}$ edn. Cambridge: CUP.

Lyons, J. (1977). Semantics. Vol.2. Cambridge: CUP. https://doi.org/10.1017/CBO9781139165693

Lyons, J. (1996). Linguistic Semantics.: An Introduction. Cambridge: CUP.

Matthews, P. H. (2007). Oxford Concise Dictionary of Linguistics. $2^{\text {nd }}$ edn. Oxford: OUP.

Onions, C. T. (1980). Modern English Syntax. London: Routledge and Kegan Paul.

Quirk, R., Sidney, G., Geoffrey, L., \& Jan, S. (1985). A Comprehensive Grammar of the English language. London: Longman.

Palmer, F. R. (1966). A Linguistic Study of the English Verb. London: William Clowes and sons.

Palmer, F. R. (1997). Semantics. $2^{\text {nd }}$ edn. Cambridge: CUP.

Stageberg, Norman, C. (1981). An Introductory English Grammar. New York: Holt, Rinehart and Winston.

Swan, M. (2009). Practical English Usage. $2^{\text {nd }}$ edn. Oxford: Oxford University Press.

Tallerman, M. (1998). Understanding Syntax. London: Arnold.

Teschner, Richard, V., \& Evans, Eston, E. (2007). Analyzing the Grammar of English. $3^{\text {rd }}$ edn. Washington: GUP.

Thomson, A.J., \& Martinet, A. V. (2001). A Practical English Grammar. ${ }^{\text {th }}$ edn. Oxford: OUP. Cambridge EnglishArabic Dictionary Online. Dictionary.cambridge.org/dictionary/English-arabic.

Wallace, E. (2004). A Basic Course in Iraqi Arabic. Washington, D. C. : Georgetown University Press.

\section{Arabic References}

Al- Ba9labaki, RuHi, \& Mmuniir Al- Ba9labaki. (2006). Almawrid AlwasiiT Almuzdawaj (Arabic- English, English-Arabi)c. $1^{\text {st }}$ edn. House of Science for Millions.

Al AHmedi, Musa bin MoHammed Al Milyany (1979). Mu9jam al?af9al Almuta9adiya biHaruf (Lexicon of the Transitive Verbs with a Letter). $1^{\text {st }}$ edn. Beirut: House of Science for Millions.

Al AnSary, ibn hiš̉am. $\dot{\check{S} a r i H ~ s ் i D u u r ~ A l D a h a b . ~ T a H q i i q ~ M u H a m m e d ~ M u H i y ~ A d i i n ~ 9 a b d u l ~ H a m i i d . ~}$

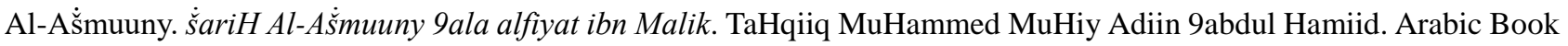
House.

A19askary, abu hilal bin 9abdallah bin sahil (2003). "alfuruuq alluǵawiyah (Linguistic Differences. 2nd edn. Scientific Books House.

Al- Duury, MoHammed Yas xuṣur (2005). daqayq ?alfuruuq ?alluǵawiyah fy ?albayan ?alqur?any. (Details of Linguistic Differences in Quran Style). Unpublished PH.D Dissertation. University of Baghdad: College of Education/ Ibn-Rushd.

Al- Farraa?, abu Zakariyah YaHya bin Ziyad (1955). Ma9any Alqur?an (Meanings of Al- Quran. Cairo: House of Egyptian Books for Translation and Authorizing.

Al Hamaš̀, K.I. (1986). Dictionary of Linguistic and Phonetic Terms: English-Arabic. Baghdad: IDELTI Publication.

Al-Maliky, Jalal Adiin abi 9umar 9u@man ibn Al Hajib (2000). Al kafiyah fy al NaHu. (AlKafiyah in Grammar). $1^{\text {st }}$ edn. Cairo: World of Books.

Al- Mubarrad, Al9abas MuHammed (1994). Al-Muqtașab (The Gained) TaHqiq MoHammed 9abdul xaliq 9aṭimah. Cairo: Al-Awqaf Ministry. The Higher Assembly for Islam Affairs.

Alsamarra?i, fașil SaliH (2005). Ma9any Al NaHu (Meanings of Grammar). $3^{\text {rd }}$ edn. Jordan: House of Thought for Printing, Publishing, and Distribution. The First and Fourth Parts.

AlӨwiny, hatif BriHy šiyaa9. Al?af9al fy Alqur?an Alkariim wa dalalatihi fy Alsiyaq Alqur?any (Verbs in the Holy Quran 
and their Meanings in the Quran Style: Alif letter). University of Qadissiya: Opening Educational College. Magazine of Arabic Language and its Arts. No. 8.PP 182-234.

Al-Zikaš̀y, Badr Adiin 9abdullah (1957). Alburhan fy 9uloom Alqur?an. (The Proof in the Quran Sciences. TaHqiq MoHammed abi Alfașil Ibrahiim.

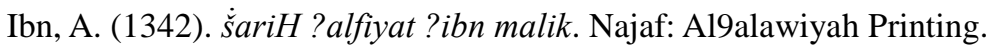

Ibn, A. (2010). Kitab Alaf9al. (Book of Verbs). TaHqiq 9aly Mawada. Cairo: Alxunčy Library for Printing, Publishing and Distribution.

9abdul Hamiid, M. M. A. (2010). ŚariH ibn 9aqiil 9ala Alfiyat ibn Malik. $2^{\text {nd }}$ edn. Baǵhdad: Bahjat Alma9rifah Company. Wehr, H.(1980). A Dictionary of Modern Written Arabic. $3^{\text {rd }}$ edn. Beirut: Lebanon Library.

Mu9jam Alma9any Aljamy: Arabic-Arabic. (2014). Available at: http://www.almaany.com/ar/dict/ar-en/

\section{Contrastive References}

Aziz, Y. (1989). A Contrastive Grammar of English and Arabic. Baghdad: Ministry of Higher Education and Scientific Research.

Khalil, A. (1999). A Contrastive Grammar of English and Arabic. Amman: Jordan Book Centre Company Limited. 


\section{Appendix (List of Iraqi Arabic Phonemic Inventory)}

1. The Consonants

\begin{tabular}{|c|c|c|}
\hline Symbol & Description & Example \\
\hline /f/ & Voiceless labio-dental fricative & fiil (elephant) \\
\hline$/ \Theta /$ & Voiceless interdental fricative & Өamir (a name of a person) \\
\hline /D/ & Voiced interdental fricative & Dalika (That is it) \\
\hline /S/ & Voiceless dental emphatic fricative & Sabir (patient) \\
\hline /ṣ/ & Voiced interdental emphatic fricative & maraș (disease) \\
\hline /T/ & Voiceless dental emphatic stop & Tara (it flew) \\
\hline$/ \mathrm{t} /$ & Voiced dental emphatic stop & țahar (back) \\
\hline$/ \mathrm{s} /$ & Voiceless dental fricative & sahil (easy) \\
\hline $\mid \mathrm{z} /$ & Voiced dental fricative & zarafa (giraffe) \\
\hline /亡̈/ & Voiceless palatal fricative & ?iš̀tara (He bought) \\
\hline$/ \check{c} /$ & Voiceless palatal affricate & bačir (tomorrow) \\
\hline$/ x /$ & Voiceless velar fricative & ?axy (my brother) \\
\hline /ǵ/ & Voiceless velar fricative & ǵariib (stranger) \\
\hline$/ \mathrm{h} /$ & Voiceless glottal fricative & hoor (marsh) \\
\hline /H/ & Voiceless pharyngeal fricative & Hamil (pregnant) \\
\hline$/ \mathrm{b} /$ & Voiced bilabial stop & bab (door) \\
\hline$/ \mathrm{t} /$ & Voiceless dental stop & timan (rice) \\
\hline$/ \mathrm{k} /$ & Voiceless velar stop & maksuur (broken) \\
\hline /g/ & Voiced velar stop & gaal (He said) \\
\hline /q/ & Voiceless post-velar stop & qawl (saying) \\
\hline /?/ & Glottal stop & ?ahl (family) \\
\hline /j/ & Voiced palatal affricate & ?ija (He came) \\
\hline$/ \mathrm{p} /$ & Voiceless bilabial stop & \\
\hline$/ \mathrm{d} /$ & Voiced dental stop & damar (destruction) \\
\hline$/ \mathrm{v} /$ & Voiced labio-dental fricative & villa \\
\hline 19/ & Voiced pharyngeal fricative & 9ayn (eye) \\
\hline$/ \mathrm{m} /$ & Voiced bilabial nasal & masaa? (evening) \\
\hline$/ \mathrm{n} /$ & Voiced dental nasal & niil (Nile river) \\
\hline$/ 1 /$ & Voiced alveolar lateral & lisan (tongue) \\
\hline$/ \mathrm{r} /$ & Voiced alveolar flap & rama (He threw) \\
\hline$/ \mathrm{w} /$ & High back rounded semi-vowel & wayana (with us \\
\hline$/ \mathrm{y} /$ & High front unrounded semi-vowel & yamnah (beside us) \\
\hline
\end{tabular}


2. The Vowels

\begin{tabular}{|l|l|l|}
\hline /i/ & Short Half-Close Front with Lip Spreading Vowel & Hamid (name of person) \\
\hline /ii/ & Long Close Front with Lip Spreading Vowel & Ibrahiim (name of person) \\
\hline /a/ & Short Half- Open Central Neutral Vowel & Sawfa (It will....) \\
\hline /aa/ & Long Open- Central Neutral Vowel & 9aaly (high) \\
\hline /u/ & Short Half-Close Back Rounded Vowel & Ummi (my mother) \\
\hline /uu/ & Long Close Back Rounded Vowel & Duury (name of person) \\
\hline /oo/ & Long half-close to half -open back rounded vowel & Tilifoon (telephone) \\
\hline
\end{tabular}

The symbols are taken from Wallace (2004: 3-4). The examples are invented by the researchers.

\section{Copyrights}

Copyright for this article is retained by the author(s), with first publication rights granted to the journal.

This is an open-access article distributed under the terms and conditions of the Creative Commons Attribution license (http://creativecommons.org/licenses/by/4.0/). 